\title{
PENILAIAN RISIKO LINGKUNGAN TERHADAP PENGARUH DARI PENGOLAHAN PUPUK ORGANIK DI RUMAH SAMPAH LAKESSI BERSAHAJA DI KELURAHAN LAKESSI KABUPATEN SIDENRENG RAPPANG
}

\author{
Enviromental Risk Assessment of the Influence of Processing Organic Fertilizerin at \\ Rumah Sampah Lakessi Bersahaja
}

Asny Septiani, Rahmi Amir, Nurhaeda, Rahmat Zarkasyi R

(Program Studi Kesehatan Masyarakat Fakultas Ilmu Kesehatan Universitas Muhammadiyah

Parepare) (asnyseptiani@gmail.com)

\begin{abstract}
ABSTRAK
Pengolahan pupuk organik yang berasal dari sampah organik ditemukan bahaya yang terkandung di dalamnya sehingga dapat menyebabkan keterpaparan pada pekerja dalam melakukan pengolahan pupuk organik yang berpotensi berbahaya, kita ketahui bahwa pupuk organik baik untuk tanaman tapi tidak diketahui dampak dari pengolahan pupuk organik.Tujuan penelitian ini untuk mengetahui risiko lingkungan terhadap pengaruh dari pengolahan pupuk organik baik dari segi efek secara langsung maupun dari segi efek secara tidak langsung di Rumah Sampah Lakessi Bersahaja Kelurahan Lakessi Kabupaten sidenreng Rappang.Metode yang digunakan dalam penelitian ini adalah metode deskriptif Peneliti mengidentifikasi melalui observasional dengan menggunakan kuesioner pada sampel, dimana sampel dalam penelitian ini pekerja yang melakukan pengolahan pupuk organik sebanyak 8 orang. Data dianalisis secara univariat dan bivariat menggunakan uji statistik Chi Square dan Fisher's Exact Test. Hasil penelitian menunjukkan bahwa ada pengaruh risiko kesehatan $(0,036<0,05)$, dan ada estimasi secara langsung $(0,036<0,05)$ dari penilaian risiko lingkungan terhadap pengaruh dari pengolahan pupuk organik di Rumah sampah Lakessi Bersahaja Kelurahan Lakessi Kabupaten Sidenreng Rappang. Hendaknya pemerintah pusat memperhatikan lokasi sebelum membangun suatu tempat pengolahan sampah karena lokasi tersebut dekat dengan sarana pendidikan, dan bagi pengelolah ruimah sampah Lakessi Bersahaja Kelurahan Lakessi Kabupaten Sidenreng Rappang, Untuk menyiapkan APD bagi para pekerja.
\end{abstract}

Kata Kunci : Penilaian risiko lingkungan, pupuk organik, risiko kesehatan, efek keterpaparan

\begin{abstract}
The processing of organic fertilizers is found to have hazards contained therein so that it can cause exposure to works in processing potentially dangerous organic fertilizers, we know that organic fertilizers are good for plants but the impact of processing organic fertilizers is unknown. The purpose of this study was to determine the environmental risk of the influence of processing organic fertilizer both in terms of direct and indirect effects in the Rumah Sampah Lakessi Bersahaja Kelurahan Lakessi Kabupaten sidenreng Rappang.The method used in this research is descriptive method, the researcher identifies through observational by using a questionnaire in the sample, the sample in this research are the worker who processed 8 organic fertilizers. Data were analyzed by
\end{abstract}


univariate and bivariate using Chi Square dan Fisher's Exact Test. The result from this research that there was an effect of health risk $(0,036<0,05)$, and there was a direct estimate $(0,036<0,05)$ of environmental risk assessment of the influence of organic fertilizer processing in the Rumah Sampah Lakessi Bersahaja Kelurahan Lakessi Kabupaten Sidenreng Rappang. The central government should pay attention to the location before building a waste processing site because the location is close to educational facilities, and for the modest Rumah Sampah Lakessi Bersahaja, Kelurahan Lakessi Kabupaten Sidenreng Rappang, to prepare personal protective equipment for workers.

Keywords : Environmental risk assessment, organic fertilizer, health risks, exposure effect 


\section{PENDAHULUAN}

Upaya pengendalian pencemaran di Indonesia sampai saat ini masih mengalami banyak kendala. Sebagian dari penghasil bahan pencemar masih belum melakukan pengolahan terhadap limbahnya karena adanya berbagai kendala antara lain kurangnya kesadaran bahwa pengelolaan bahan organik merupakan investasi jangka panjang yang harus dilakukan, kurangnya informasi teknologi IPAL yang efektif dan efisien serta kurangnya sumber daya manusia yang menguasai teknologi IPAL. Adanya Interaksi agen lingkungan (kimia, fisik, biologi) dan aktifitas manusia saling mempengaruhi terhadap kesehatan. Saat ini tiga macam bentuk ancaman bahaya lingkungan yaitu zat-zat kimia toksik, energi berbahaya (radiasi dan gelombang elektromagnetik) dan organisme patogen.

Karena sebagian besar pabrik pupuk organik yang ada memiliki dampak terhadap proses pembuatan dan keberadaan pabrik tersebut terhadap masyarakat sekitar karena menimbulkan bau yang berasal dari limbah pabrik pupuk organik dan menimbulkan dampak terhadap lingkungan. Persoalan tersebut semakin komplek, akibat tingkat pemahaman tentang lingkungan dan sistem manajemen limbah oleh pengelolah maupun tingkat ketaatan terhadap hukum lingkungan yang masih kurang serta lemahnyapenegakkan hukum lingkungan yangberlaku. Adapun Jenis-jenis pupuk organik yang pada umumnya diketahui yaitu pupuk kandang, Pupuk dingin, pupuk hijau, pupuk kompos, dan pupuk organik buatan.

Tidak hanya dari segi lingkungan akan tetapi juga berdampak pada kesehatan masayarakat itu sendiri akibat terpaparnya oleh kuman pathogen yang berasal dari sampah organik dan menimbulkan penyakit seperti diare, kolera, tifus menyebar dengan cepat karena bakteri yang berasal dari sampah dengan pengelolaan tidak tepat dapat bercampur air minum. Penyakit demam berdarah (haemorhagic fever) dapat juga meningkat dengan cepat di daerah yang pengelolaan sampahnya kurang memadai, Penyakit jamur dapat juga menyebar (misalnya jamur kulit), Penyakit yang dapat menyebar melalui rantai makanan. Salah satu contohnya adalah suatu penyakit yang dijangkitkan oleh cacing pita (taenia). Cacing ini sebelumnya masuk ke dalam pencernaan binatang ternak melalui makanannya yang berupa sisa makanan/sampah, Penyakit Legionella longbeachae yang merupakan penyakit Pneumonia di paru-paru kiri disebabkan oleh bakteri legionella pneumophili yang ditemukan pada tanah khususnya pada kompos. Adapun pathogen yang terdapat pada sampah organik yaitu powder ( Berisi bakteri aktinomycetes-spesies aktinomy

cesnaeslundii, 
Lactobacillus spesiesdelbrueckii,Bacillu Brevi s,Sacchar omyces Cerevisiae, ragi, dan jamur serta Cellulolytic Bacillus Sp), Escherichia Coli. ${ }^{2}$

Konsep dan pentahapan kajian risiko sangat tergantung pada subjek yang akan dikaji. Subjek kajian dapat berupa estimasai secara langsung misalnya munculnya bau pada proses pembuatan pupuk, pencemaran air, terganggunya estetika dan memiliki potensi untuk menimbulkan risiko baik bagi kesehatan maupun lingkungan.Secara umum dikenal pentahapan kajianrisiko, yang tingkat kedalamnanya berbeda-beda tergantung subyek yang akan dikaji serta manusia atau lingkungan yang akan menerima risikotersebut.

Lingkungan sehat yang diharapkan adalah lingkungan hidup yang terencana, terorganisasi dilihat dari faktor yang ada dalam lingkungan fisik manusia, dikelolah sedemikian rupa sehingga derajat kesehatan dapat ditingkatkan. Ditinjau dari sudut kepentingan masyarakat dalam berinteraksi dengan lingkungan masih banyak sekali masalah lingkungan yang perlu diperhatikan. Kebanyakan masyarakat terutama yang hidup di daerah pedesaan belum mengetahui masalah lingkungan disekitarnya yang dapat berakibat buruk terhadap kesehatan dan kelangsungan hidup mereka.

Keadaan dan masalah lingkungan yang berkaitan dengan kesehatan masyarakat nampak sangat beragam. Berbagai faktor lingkungan yang merugikan belum dapat dihadapi, hal ini yang mempengaruhi terjadinya berbagai pola penyakit dimasyarakat.

Saat ini penyakit menular berbasis lingkungan masih menjadi masalah utama bagi masyrakat khususnya di daerah pedesaan dan permukiman yang padat penduduknya dan pada tempat pengolahan pupuk organik dimana pengetahuan tentang perilaku sehat masih masalah penting bagi para masyarakat yang bekerja disana sehingga penyakit berbasis lingkungan sewaktu waktu dapat dialami oleh masyarakat sendiri/pekerjanya .

Penilaian risiko kesehatan lingkungan atau yang juga dikenal dengan Environmental Health Risk Assessment (EHRA) adalah studi untuk memahami kondisi fasilitas sanitasi dan perilaku-perilaku yang berisiko pada kesehatan masyarakat. Seperti perilaku Cuci Tangan Pakai Sabun (CTPS) dan perilaku pemilahan sampah dan buang air besar sembarangan, pada penelitian ini juga akan dilakukan seberan atau pemetaan risiko kesehatan lingkungan. ${ }^{3}$

Secara nasional, bahaya yang muncul dari permasalahan lingkungan dan faktorfaktor risiko kebersihan serta perilaku yang tidak higienis atau berisiko, pada proses pengolahan pupuk organik menyumbang $19 \%$ kematian di dunia akibat penyakit-penyakit infeksi. Masalah kesehatan lingkungan di 
Indonesia, dalam hal ini adalah sarana sanitasi pulau-pulau kecil dan daerah terisolir masih sangat memprihatinkan yang ditandai dengan masih tingginya angka kejadian penyakit infeksi dan penyakit menular di masyarakat.

Saat ini terdapat kecenderungan perubahan pendekatan dalam kebijakan dan regulasi lingkungan dari yang berdasarkan bahaya (hazard-based) menjadi berdasarkan risiko (risk-based). Pendekatan berdasarkan risiko adalah dengan cara mengevaluasi risiko aktual dari suatu isu lingkungan tertentu, sedangkan pendekatan berdasarkan bahaya adalah mengkaji potensi bahaya yang kemungkinan muncul atau tidakmuncul.

Kajian risiko juga memerlukan evaluasi apakah risiko dalam prakteknya memiliki arti ke komponen lingkungan yang dipengaruhinya. Hal ini sangat tergantung apakah risiko yang sedang dikaji dapat diterima. Evaluasi risiko secara fundamental subyektif dan berdasarkan alasan tersebut banyak praktisi lebih suka untuk memisahkannya dari pentahapan pendugaan risiko yang lebih "ilmiah". Isu lain yang penting dalam kajian risiko, terutama bagi pihak yang menginginkan penilaian terhadap keputusan yang muncul dari hasil kajian risiko, adalah memisahkan antara kajian risiko dan manajemen risiko. ${ }^{4}$

Berdasarkan uraian latar belakang tersebut, maka peneliti bermaksud melakukan penelitian tentang "Penilaian risiko lingkungan terhadap pengaruh dari pengolahan pupuk organik di rumah sampah lakessi bersahaja di kelurahan lakessi kabupaten sidenreng rappang ".

Tujuan penelitian ini adalah untuk mengetahuipengaruh dari pengolahan pupuk organik di rumah sampah lakessi bersahaja di kelurahan lakessi kabupaten sidenreng rappang".

\section{BAHAN DAN METODE}

Desain penelitian ini menggunakan metode penelitian deskriptif denganmenggunakan Study literature yang digunakan sebagai acuan untuk membuat kuesioner penelitian. Populasi dan Sampel dalam penelitian ini sebanyak 8 orang. Penelitian ini menggunakan total sampling .Variabel independen dalam penelitian ini adalahPenilaian Risiko Lingkungan Terhadap Pengaruh dari Pengolahan Pupuk Organik terhadap Risiko Kesehatan dan Efek keterpaparan. Data primer mencakup segala informasi tentang penilaian risisko lingkungan yang menjadi obyek penelitian.Data sekunder merupakan data yang diperoleh dari instansiinstansi/lembaga- lembaga terkait, yaitu Puskesmas Pangkajenne untuk mengambil data profil penyakit berbasis lingkungan (PBL) yang kemungkinan terjadi. Data yang sudah diolah, diuji dengan uji Chi Square nilai signifikan (nila $p$ ), jika nilai $p<0,05$ maka $\mathrm{H}_{0}$ ditolak sehingga adapengaruh dari penilaian 
risiko lingkungan terhadap pengolahan pupuk organik pada risiko kesehatan di Rumah sampah Lakessi Bersahaja kelurahan Lakessi Kabupaten Sidenreng Rappang.

\section{HASIL}

Distribusi frekuensi pada karakteristik responden menunjukkan bahwa dari total 8 responden, umur responden yang tertinggi terdapat pada kelompok umur 31 - 35 tahun yaitu sebanyak 3 orang $(37,5 \%)$ dan umur responden yang terendah terdapat pada kelompok umur 26-30 tahun yaitu sebanyak 1 orang (12,5\%). Distribusi responden berdasarkan jenis kelamin menunjukkan bahwa dari total 8 responden, yang berjenis kelamin laki-laki sebanyak 2 orang (25\%) dan responden yang berjenis kelamin perempuan sebanyak 6 orang (75\%). Distribusi responden berdasarkan pendidikan terakhir menunjukkan bahwa dari total 8 responden, pendidikan terakhir responden yang tertinggi terdapat pada jenjang pendidikan SD yaitu sebanyak 4 orang $(50 \%)$ dan pendidikan terakhir responden yang terendah terdapat pada jenjang pendidikan SMP/Sederajat yaitu sebanyak 1 orang (12,5\%). Distribusi responden berdasarkan status perkawinan menunjukkan bahwa dari total 8 responden, yang sudah menikah sebanyak 6 orang $(75 \%)$ dan responden yang belum menikah sebanyak 2 orang $(25 \%)$.
Distribusi responden berdasarkan risiko kesehatan dan efek keterpaparan menunjukkan bahwa dari total 8 responden didapatkan pada risiko kesehatan, responden yang memiliki pengaruh pada kesehatannya yaitu 6 orang $(75 \%)$ dan yang tidak memiliki pengaruh pada kesehatannya ada 2 orang (25\%). Dan pada Efek Keterpaparan responden yang memiliki pengaruh pada kesehatannya yaitu 6 orang (75\%) dan yang tidak memiliki pengaruh pada kesehatannya ada 2 orang $(25 \%)$.

Penilaian risiko lingkungan terhadap pengaruh dari pengolahan pupuk organik terhadap risiko kesehatan menunjukkan bahwa dari 2 responden yang memiliki penilaian risiko lingkungan yang baik, tidak ada orang $(0,0 \%)$ yang mendapatkan pengaruh pada risiko kesehatannya, sedangkan 2 orang $(50,0 \%)$ yang tidak mendapatkan pengaruh pada risiko kesehatan, sedangkan dari 6 responden yang tidak memiliki penilaian risiko yang baik, 4 orang $(100,0 \%)$ yang memiliki pengaruh pada risiko kesehatan dan 2 orang $(50,0 \%)$ yang tidak memiliki pengaruh pada risiko kesehatan. Berdasarkan hasil uji statistik dengan menggunakan Fisher's Exact

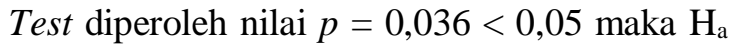
diterima dan $\mathrm{H}_{0}$ ditolak sehingga disimpulkan bahwa ada pengaruh dari penilaian risiko lingkungan terhadap pengolahan pupuk organik pada risiko kesehatan di Rumah 
sampah Lakessi Bersahaja kelurahan Lakessi Kabupaten Sidenreng Rappang.

Penilaian risiko lingkungan terhadap pengaruh dari pengolahan pupuk organik terhadap efek keterpaparan menunjukkan bahwa pada penilaian risiko lingkungan dari 2 responden yang memiliki penilaian yang baik, tidak ada orang $(0,0 \%)$ yang mendapatkan estimasi secara langsung pada efek keterpaparan, 2 orang $(50,0 \%)$ yang mendapatkan estimasi secara tidak langsung pada efek keterpaparan, sedangkan dari 6 responden yang tidak memiliki penilaian yang baik, 4 orang $(100,0 \%)$ yang mendapatkan estimasi secara langsung pada efek keterpaparan dan 2 orang $(50,0 \%)$ yang mendapatkan estimasi secara tidak langsung pada efek keterpaparan. Berdasarkan hasil uji statistik dengan menggunakan Fisher's Exact Test diperoleh nilai $p=0,036<0,05$ maka $\mathrm{H}_{\mathrm{a}}$ diterima dan $\mathrm{H}_{0}$ ditolak sehingga disimpulkan bahwa ada pengaruh dari penilaian risiko lingkungan terhadap pengolahan pupuk organik pada efek keterpaparan di Rumah sampah Lakessi Bersahaja kelurahan Lakessi Kabupaten Sidenreng Rappang.

\section{PEMBAHASAN}

Hasil penelitian yang telah dilakukan tentang penilaian risiko lingkungan terhadap pengaruh dari pengolahan pupuk organic di Rumah Sampah Lakessi Bersahaja Kelurahan Lakessi Kabupaten Sidenreng Rappang Tahun
2018, maka ditinjau dari analisis karakteristik responden berdasarkan kelompok umur diketahui semua responden berada pada usia produktif, dimana di usia ini harusnya manusia dapat bekerja dan menghasilkan sesuatu yang bermanfaat untuk keberlangsungan hidupnya.

Ditinjau dari analisis karakteristik responden berdasarkan jenis kelamin diketahui responden yang berjenis kelamin perempuan lebih banyak dari pada laki-laki. Hal ini disebabkan karena semua perempuan yang bekerja di rumah sampah tersebut merupakan ibu rumah tangga yang mencari penghasilan sampingan dengan bekerja disana untuk memenuhi kebutuhan hidupnya. Ditinjau dari analisis karakteristik responden berdasarkan tingkat pendidikan terakhir responden dari penelitian ini tertinggi adalah jenjang SMA/sederajat. Jika dilihat dari tingkat pendidikan yang ditempuh, seharusnya responden sudah mempunyai pengetahuan dan pemahaman yang cukup mengenai risiko lingkungan yang terjadi di lokasi kerja mereka .Ditinjau dari analisis karakteristik responden berdasarkan status perkawinan dapat dilihat bahwa kebayakan reponden yang sudah menikah dari pada yang menikah.

Lingkungan merupakan subjek yang paling banyak mengalami risiko baik oleh akibat kondisi alam maupun oleh tindakan manusia seperti adanya pelepasan zat berbahaya ke lingkungan. Sesuai dengan defenisinya maka risiko lingkungan 
merupakan perkalian frekuensi kejadian kecelakaan dengan dampak lingkungannya. Artinya besaran risiko lingkungan menunjukkan tingkat dampak dari sesuatu tindakan manusia atau alam terhadap lingkungan, baik terhadap manusia itu sendiri maupun terhadap ekologi. ${ }^{5}$

Penilaian risiko lingkungan adalah proses menilai faktor lingkungan akibat pemanfaatan sumber daya alam dalam proses produksi dan konsumsi yang dilakukan oleh manusia.Lingkungan sehat yang diharapkan adalah lingkungan hidup yang terencana,terorganisasi dilihat dari faktor yang ada dalam lingkungan fisik manusia, dikelolah sedemikian rupa sehingga derajat kesehatan dapat ditingkatkan. Ditinjau dari sudut kepentingan masyrakat dalam berinteraksi dengan lingkungan masih banyak sekali masalah lingkungan yang perlu diperhatikan. Kebanyakan masyarakat terutama yang hidup di daerah pedesaan belum mengetahui masalah lingkungan disekitarnya yang dapat berakibat buruk terhadap kesehatan dan kelangsungan hidup mereka. Keadaan dan masalah lingkungan yang berkaitan dengan kesehatan masyarakat nampak sangat beragam. Hasil uji statistik dengan menggunakan Fisher's Exact Test diperoleh nilai $p=0,036<0,05$ maka $\mathrm{H}_{\mathrm{a}}$ diterima dan $\mathrm{H}_{0}$ ditolak sehingga disimpulkan bahwa ada pengaruh dari penilaian risiko lingkungan terhadap pengolahan pupuk organik pada risiko kesehatan di Rumah sampah Lakessi Bersahaja kelurahan Lakessi Kabupaten Sidenreng Rappang. Hasil wawancara dengan kuesioner diperoleh bahwa terdapat dampak yang ditimbulkan dari pengolahan pupuk organik seperti menimbulkan bau dilokasi tersebut dimana bau tersebut yang dihirup mengandung gas yang bebahaya bagi kesehatan pekerja itu sendiri, pencemaran air disekitar rumah sampah tersebut menjadi tercemar yang diakibatkan oleh kandungan kimia yang terdapat pada sampah tersebut, terganggunya estetika karena lokasi yang berdekatan dengan sarana pendidikan. Apabila diperhatikan secara seksama dapat mengnggu jalannya proses belajar mengajar, oleh karena itu pengolahan sampah untuk pupuk organik sebaiknya dijauhkan dari tempat dari fasilitas umum seperti sekolah, tempat ibadah, sarana kesehatan, pasar dan lain-lain.

$$
\text { Efek keterpaparan terhadap }
$$

lingkungan dari proses pembuatan pupuk organik adalah estimasi keterpaparan terhadap lingkungan dan manusia yang dapat menimbulkan penurunan kualitas air dan kualitas kesehatan yang dapat meningkatkan angka kejadian penyakit WBD dan FBD.Dimana terdapat pula bahaya pada sampah organik yang dapat menyebabkan keterpaparan pada pekerja dalam pengolahan pupuk organik potensi bahaya yang terjadi 
seperti penyakit Water Borne Disease (WBD) dan Food Borne Disease (FBD).

Beberapa penyakit juga dapat terjadi akibat adanya vektor penyakit yang tinggal di air seperti malaria (disebabkan protozoa Plasmodium dengan vektor nyamuk), dan demam berdarah (disebabkan oleh virus dengan vektor nyamuk). Water-borne diasease diakibatkan oleh mikroorganisme berupa bakteri, protozoa, dan cacing. Bakteri penyebab water atau foodborn disease antara lain:Chlostridium botulinum, Campylobacter jejuni, Vibrio cholerae, Vibrio parahaemolyticusEscherichia coli, Shigella dysenteriae, Salmonella typhi.Untuk bakteri dan protozoa umumnya menyebabkan sakit akibat masuknya organisme tersebut dapat merusak jaringan ataupun sistem sirkulasi pada saluran pencernaan. Hal inilah yang menyebabkan pencernaan tidak bekerja optimal sehingga menyebabkan diare bagi penderita. Kondisi yang lebih parah dapat menyebabkan kerusakan pada saluran pencernaan sehingga menyebabkan luka saluran cerna yang berakibat pada diare beradarah. Diare yang cukup sering dapat berbahaya bagi manusia diakibatkan kekurangan cairan pada tubuh, dan kehilangan cairan parah dapat menyebabkan keseimbangan asam basa tubuh tidak seimbang yang berujung pada kerusakan sistem organ.. ${ }^{6}$
Hasil uji statistik dengan menggunakan Fisher's Exact Test diperoleh nilai $p=0,036<0,05$ maka $\mathrm{H}_{\mathrm{a}}$ diterima dan $\mathrm{H}_{0}$ ditolak sehingga disimpulkan bahwa ada pengaruh dari penilaian risiko lingkungan terhadap pengolahan pupuk organik pada efek keterpaparan di Rumah sampah Lakessi Bersahaja kelurahan Lakessi Kabupaten Sidenreng Rappang.

Hasil wawancara dengan mengisi kuesioner, peneliti menemukan bahwa kebanyakan dari pekerja tidak mengguanakan Alat Pelindung Diri (APD) pada saat bekerja itu mengakibatkan mudah terpapar oleh bakteri pathogen yang terdapat pada sampah organik yang dijadikan bahan untuk membuat pupuk organik karena bila terkontaminasi pada bakteri tersebut dapat mempengaruhui kesehatan dan menimbulakn gangguan kesehatan pada pekerja itu sendiri seperti apabila tidak menggunakan sarung tangan saat mengolah sampah menjadi pupuk organik maka akan menimbulkan jamur pada kulit dan gangguan pada kulit lainnya seperti gatalgatal. Sehingga perlu ditingkatkannya sistem manajemen risiko untuk mengurangi risiko yang terjadi .

Karena pada pekerja yang memakan makanan disana pada saat istirahat kebanyakan pekerja hanya mencuci tangan memakai air tanpa sabun sehingga itu tidak memastikan mereka terhindar dari kuman dan apabila menyentuh makanan dan ditangannya 
terdapat kuman maka dapat menyebabkan penyakit Food Borne Disease (FBD) yaitu penyakit yang disebabkan karena makanan seperti diare.

\section{KESIMPULAN DAN SARAN}

\begin{abstract}
Berdasarkan hasil penelitian yang dilakukan di Rumah Sampah Lakessi Bersahaja Kelurahan Lakessi Kabupaten Sidenreng Rappang, dapat disimpulkan bahwa ada pengaruh dari penilaian risiko lingkungan terhadap pengolahan pupuk organik dari segi efek secara langsung maupun tidak langsung di Rumah Sampah Lakessi Bersahaja Kelurahan Lakessi Kabupaten Sidenreng Rappang dengan $P$ Value $0,036<0,05$. Selanjutnya disarankan bagi pekerja yang melakukan pengolahan pupuk organik diharapkan tetap memperhatikan kesehatan
\end{abstract}

\section{DAFTAR PUSTAKA}

1. Greenplanet. Jenis Pupuk Organik. [serial online]; 2015. [Diakses tanggal 22 Maret 2018] at http:/

/www.greenplanet.co.id /index.php/post/70/Jenis+Pupuk+Orga nik.

2. Detik Health. Bahaya Kesehatan Mengintai dari Pupuk Kompos. [serial dengan menerapkan perilaku hidup bersih dan sehat (PHBS) agar tidak mudah terpapar oleh mikroorganisme pathogen yang dapat menimbulkan penyakit, bagi pengelola Rumah Sampah Lakessi Bersahaja diharapkan dapat menyediakan Alat Pelindung Diri yang khusus dan menerapkan aturan kepada pekerja untuk memakai APD saat bekerja sehingga dapat mengurangi risiko keterpaparan mikroorganisme pada pekerja yang dapat mengganggu kesehatan. Sebaiknya menggunakan Alat Pelindung diri (APD) pada saat bekerja seperti sarung tangan, masker, sepatu both dan lain-lain, dan Bagi Pemerintah Pusat hendaknya memperhatikan lokasi sebelum membangun suatu tempat pengolahan sampah karena melihat dari lokasi tersebut kurang strategis karena letaknya yang dekat dengan sarana pendidikan.

online]; 2010. [ Diakses tanggal 23 maret 2018] at https://health.detik.com/beritadetikhealth/1436217/bahaya-kesehatanmengintai-dari-pupuk-kompos.

3. Paper, C. Penilaian Risiko Lingkungan (Environmental Risk Assessment) Pada Pekerjaan Bangunan ...., (December) [jurnal online]; 2016: 0-5 
4. Santosa , D. A. Kajian Risiko Lingkungan untuk Penggunaan Agen Hayati Di Bidang Pertanian Environmental Risk Assessment For Uses Of Biological Agents For Agriculture. Nal Tanah Dan Lingkungan; 2009: 11(1), 14-20.

5. Ergani, I. Analisis Risiko Lingkungan. [serial online]; 2009. [Diakses tanggal 24 Maret 2018] at http://inganergani.blogspot.co.id/2009/02/ Analisis-risiko-lingkungan.html.

6. Juragan Riview. Water Borne Disease(Penyakit yang Ditularkan melalui Air). [serial online]; 2016. [Diakses tanggal 24 Maret 2018] at https://juraganriview.blogspot.com/20 16/03/water-borne-disease-ataupenyakit-html?m=1. 


\section{LAMPIRAN}

Tabel 1. Distribusi Responden berdasarkan Kelompok Umur pada Pekerja di Rumah Sampah Lakessi

Bersahaja di Kelurahan Lakessi Kabupaten Sidenreng Rappang

\begin{tabular}{lccc}
\hline & Kelompok Umur (tahun) & F & \% \\
\hline & & 25 \\
\hline $21-25$ & 2 & 12,5 \\
$26-30$ & 1 & 37,5 \\
$31-35$ & & 3 & 25 \\
$36-40$ & Total & 2 & $\mathbf{1 0 0 , 0}$ \\
\hline
\end{tabular}

Sumber : Data Primer (2018).

Tabel 2. Distribusi Responden berdasarkan Jenis Kelamin pada Pekerja di Rumah Sampah Lakessi Bersahaja di Kelurahan Lakessi Kabupaten Sidenreng Rappang

\begin{tabular}{lccc}
\hline & Jenis Kelamin & F & \% \\
\hline Laki - laki & & 2 & 25 \\
Perempuan & Total & 6 & 75 \\
\hline & & $\mathbf{8}$ & $\mathbf{1 0 0 , 0}$ \\
\hline
\end{tabular}

Sumber : Data Primer (2018).

Tabel 3. Distribusi Responden berdasarkan Pendidikan Terakhir pada Pekerja di Rumah Sampah Lakessi Bersahaja di Kelurahan Lakessi Kabupaten Sidenreng Rappang

\begin{tabular}{lccc}
\hline & Pendidikan Terakhir & F & \% \\
\hline SD & & 4 & 50 \\
SMP/sederajat & Total & 1 & 12,5 \\
SMA/sederajat & & 3 & 37,5 \\
\hline & & $\mathbf{8}$ & $\mathbf{1 0 0 , 0}$ \\
\hline
\end{tabular}

Sumber : Data Primer (2018). 
Tabel 4. Distribusi Responden berdasarkan Status Perkawinan pada Pekerja di Rumah Sampah Lakessi

Bersahaja di Kelurahan Lakessi KabupatenSidenreng Rappang

\begin{tabular}{|c|c|c|}
\hline Status Perkawinan & $\mathbf{F}$ & $\%$ \\
\hline Menikah & 6 & 75 \\
\hline Belum Menikah & 2 & 25 \\
\hline Total & 8 & 100,0 \\
\hline
\end{tabular}

Sumber : Data Primer (2018).

Tabel 5. Distribusi Responden berdasarkan Risiko Kesehatan dan Efek Keterpaparan pada Penilaian

RisikoLingkungan terhadap Penagruh Pengolahan Pupuk Organik di Rumah Sampah Lakessi Bersahaja Kelurahan Lakessi Kabupaten Sidenreng Rappang

\begin{tabular}{|c|c|c|}
\hline Variabel & $\mathbf{F}$ & $\%$ \\
\hline \multicolumn{3}{|l|}{ Risiko Kesehatan } \\
\hline Ada Pengaruh & 6 & 75 \\
\hline Tidak Ada Pengaruh & 2 & 25 \\
\hline \multicolumn{3}{|l|}{ Efek Keterpaparan } \\
\hline Estimasi Secara Langsung & 6 & 75 \\
\hline Estimasi Secara tidak Langsung & 2 & 25 \\
\hline Total & 8 & 100,0 \\
\hline
\end{tabular}

Penilaian Risiko Lingkungan

Baik : 2

Tidak Baik : 6

Tabel 6. Penilaian Risiko Lingkungan Terhadap Pengaruh dari Pengolahan Pupuk Organik terhadap Risiko Kesehatan di Rumah sampah Lakessi Bersahaja KelurahanLekessi Kabupaten Sidenreng Rappang

\begin{tabular}{lccccccc}
\hline \multirow{2}{*}{ Risiko Kesehatan } & \multicolumn{6}{c}{ Penilaian Risiko Lingkungan } \\
\cline { 2 - 7 } & \multicolumn{2}{c}{ Baik } & \multicolumn{2}{c}{ Tidak Baik } & \multicolumn{2}{c}{ Total } & \multirow{2}{*}{$P$} \\
\cline { 2 - 8 } & $\mathrm{N}$ & $\%$ & $\mathrm{n}$ & $\%$ & $\mathrm{n}$ & $\%$ & \\
\hline Ada pengaruh & 0 & 0,0 & 4 & 100,0 & 4 & 100,0 & \multirow{2}{*}{0,036} \\
Tidak ada pengaruh & 2 & 50,0 & 2 & 50,0 & 4 & 100,0 & \\
\hline Total & 2 & 25 & 6 & 75 & 8 & 100,0 & \\
\hline
\end{tabular}

Sumber : Data Primer (2018). 
Tabel 7. Penilaian Risiko Lingkungan Terhadap Pengaruh dari Pengolahan Pupuk Organik Terhadap Efek Keterpaparan di Rumah sampah Lakessi BersahajaKelurahan Lekessi Kabupaten Sidenreng Rappang

\begin{tabular}{|c|c|c|c|c|c|c|c|}
\hline \multirow{3}{*}{ Efek Keterpaparan } & \multicolumn{7}{|c|}{ Penilaian Risiko Lingkungan } \\
\hline & \multicolumn{2}{|c|}{ Baik } & \multicolumn{2}{|c|}{ Tidak Baik } & \multicolumn{2}{|c|}{ Total } & \multirow{2}{*}{$P$} \\
\hline & $\mathrm{n}$ & $\%$ & $\mathrm{n}$ & $\%$ & $\mathrm{~N}$ & $\%$ & \\
\hline Estimasi secara langsung & 0 & 0,0 & 4 & 100,0 & 4 & 100,0 & \multirow{3}{*}{0,036} \\
\hline $\begin{array}{l}\text { Estimasi secara tidak } \\
\text { langsung }\end{array}$ & 2 & 50,0 & 2 & 50,0 & 4 & 100,0 & \\
\hline Total & 2 & 25 & 6 & 75 & 8 & 100,0 & \\
\hline
\end{tabular}

Sumber : Data Primer (2018). 